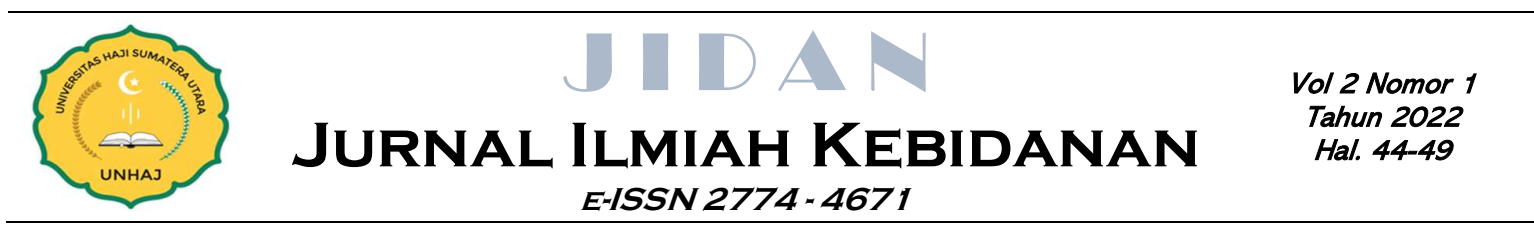

\title{
FAKTOR RISIKO UMUR IBU DAN PSIKOLOGIS DENGAN KEJADIAN HIPEREMESIS GRAVIDARUM
}

\author{
Herawaty $^{1}$, Vinny Alvionita ${ }^{2 *}$, Marwanti AW ${ }^{3}$, Hasnia $^{4}$, Nunung Erviany ${ }^{5}$, \\ Ummul Khair ${ }^{6}$, Nurfitri ${ }^{7}$, Inez Vravty Lestari ${ }^{8}$, Sumarni Syam ${ }^{9}$ \\ 1,2,4,5,6,7,8,9 Akademi Kebidanan Menara Primadani, Soppeng, Indonesia \\ ${ }^{3}$ Stikes Mega Buana Palopo, Indonesia \\ Email: ${ }^{1}$ herawaty@akbidmps.ac.id, ${ }^{2 *}$ vinnyalwi1992@gmail.com, ${ }^{3}$ lppmakbidmps@gmail.com,
${ }^{4}$ hasnia@akbidmps.ac.id, ${ }^{5}$ nunungerviany@akbidmps.ac.id, ${ }^{6}$ ummulkhair@akbidmps.ac.id,
${ }^{7}$ nurfitri@akbidmps.ac.id, ${ }^{8}$ inezlestari@akbidmps.ac.id, ${ }^{9}$ sumarnisyam@akbidmps.ac.id.
}

\begin{abstract}
ABSTRAK
Hiperemesis gravidarum adalah mual atau muntah yang berlebihan yang dapat mengganggu aktivitas sehari-hari dan bahkan dapat membahayakan kehidupan wanita hamil. Penelitian ini bertujuan untuk mengidentifikasi tingkat faktor risiko usia dan kondisi psikologis ibu dengan kejadian hiperemesis gravidarum. Penelitian ini menggunakan metode penelitian cross sectional. Populasinya adalah 25 wanita hamil dengan hiperemesis gravidarum dan 50 wanita hamil yang tidak mengalami gravidarum yang diambil dengan menggunakan purposive sampling. Data terdiri dari data primer (dikumpulkan melalui kuesioner) dan data sekunder. Data diproses menggunakan Statistical Product and Service Solution (SPSS) dan dianalisis melalui statistik univariat dan bivariat menggunakan tes Rasio Odss dan disajikan dalam tabel distribusi frekuensi. Hasil dari penelitian ini didapati faktor risiko hiperemesis gravidarum pada ibu hamil dengan usia risiko tinggi adalah 5,52 kali lebih tinggi dari pada mereka yang memiliki usia risiko rendah $(\mathrm{OR}=5,52$ atau $>1)$ dan faktor risiko hiperemesis gravidarum pada wanita hamil dengan gangguan psikologis adalah 2,95 kali lebih tinggi daripada mereka yang tidak memiliki gangguan psikologis $(\mathrm{OR}=2,95$ (atau $>1)$. Dapat disimpulkan bahwa usia ibu dan gangguan psikologis merupakan faktor risiko hiperemesis gravidarum.
\end{abstract}

Kata Kunci: Hiperemesis Gravidarum, umur ibu, psikologis.

\section{Pendahuluan}

Mual dan muntah merupakan hal yang umum terjadi pada awal kehamilan (trimester I). Mual dan muntah biasanya terjadi pada pagi hari, oleh karena itu disebut juga sebagai morning sickness, namun tidak menutup kemungkinan juga terjadi pada siang dan malam hari. Mual dan muntah yang berlebihan dan terjadi sepanjang hari sampai mengganggu pekerjaan sehari-hari dan menyebabkan dehidrasi disebut sebagai hiperemesis gravidarum (Fauziyah, 2012)

Hiperemesis gravidarum dapat menyebabkan cadangan karbohidrat habis dipakai untuk keperluan energi, sehingga pembakaran tubuh beralih pada cadangan lemak dan protein. Karena pembakaran lemak kurang sempurna terbentuklah badan keton didalam darah yang dapat menambah beratnya gejala klinik. Muntah yang berlebihan dapat menyebabkan pecahnya pembuluh darah kapiler pada lambung dan esophagus, sehingga muntah bercampur darah. Hal tersebut dapat menimbulkan kekhawatiran wanita hamil, dan mengagetkan keluarganya. Sekalipun kejadian muntah dalam bentuk hiperemesis gravidarum tidak banyak dijumpai, namun penanganannya memerlukan perhatian khusus (Manuaba, 2014). Beberapa faktor yang berpengaruh terhadap kejadian hiperemesis gravidarum meliputi faktor predisposisi terdiri dari primigravida, molahidatidosa, dan kehamilan ganda, faktor organik seperti alergi masuknya vilikohirialis sirkulasi, perubahan metabolik akibat kehamilan dan resistensi ibu yang menurun, faktor psikologis, meliputi pengetahuan, sikap, umur, paritas, pekerjaan, stress, peningkatan hormon progesterone, estrogen dan HCG, alergi, infeksi dan diabetes melitus (Warsuli, et.al., 2016).

Ketika wanita dinyatakan hamil, maka kadar hormon progesteron dalam tubuh meningkat dan ini menyebabkan timbulnya mual, muntah pada pagi hari, lemah, letih, dan membesarnya payudara. Pada awal kehamilan ini, ibu akan membenci perubahan yang terjadi pada dirinya. Banyak ibu yang merasa kecewa, 


\section{JURNAL ILMIAH KEBIDANAN \\ E-ISSN 2774 - 4671

terjadi penolakan, kecemasan dan kesedihan. Sering kali pada awal kehamilan banyak ibu yang mengharapkan untuk tidak hamil.

Kematian maternal umumnya ukuran yang dipakai untuk menilai baik buruknya keadaan pelayanan kebidanan (maternity care) dalam suatu negara atau daerah ialah kematian maternal (maternal mortality). Menurut defenisi World Health Organization (WHO) kematian maternal ialah kematian seorang wanita waktu hamil atau dalam 42 hari sesudah berakhirnya kehamilan oleh sebab apapun, terlepas dari tuanya kehamilan dan tindakan yang dilakukan untuk mengakhiri kehamilan. Sebab-sebab kematian ini dapat dibagi dalam dua golongan, yakni yang langsung disebabkan oleh komplikasi-komplikasi kehamilan, persalinan dan nifas, dan sebab-sebab yang lain seperti penyakit jantung, kanker dan sebagainya (associated causes). Angka kematian maternal (Maternal Mortality Rate) ialah jumlah kematian maternal diperhitungkan terhadap 1.000 atau 10.000 kelahiran hidup (KH), kini di beberapa Negara malahan terhadap $100.000 \mathrm{KH}$ (Prawirohardjo, 2014).

Menurut WHO tahun 2015 memperkirakan terdapat 216 kematian ibu setiap $100.000 \mathrm{KH}$ akibat komplikasi kehamilan dan persalinan tahun 2015. Jumlah total kematian ibu diperkirakan mencapai 303.000 kematian di seluruh dunia. Maternal Mortality Rate (MMR) di negara berkembang mencapai 239/100.000 KH, 20 kali lebih tinggi dibandingkan negara maju. Negara berkembang menyumbang sekitar 90\% atau 302.000 dari seluruh total kematian ibu yang diperkirakan terjadi pada tahun 2015. Indonesia termasuk salah satu negara berkembang sebagai penyumbang tertinggi angka kematian ibu (AKI) di dunia. WHO memperkirakan di Indonesia terdapat sebesar 126 kematian ibu setiap $100.000 \mathrm{KH}$ dengan jumlah total kematian ibu sebesar 6400 pada tahun 2015. Angka ini sudah terjadi penurunan dari angka kematian ibu menurut SDKI 2012 yaitu sebesar 359 per 100.000 kelahiran hidup (WHO, 2015)

Sejak 2007, Indonesia tercatat sebagai negara dengan AKI tertinggi di Asia Tenggara (UNFPA, 2013) dengan 228 kematian per 100.000 KH. Lima tahun kemudian, SDKI 2013 menunjukkan AKI di Indonesia berada pada angka 359 kematian per $100.000 \mathrm{KH}$, sedangkan target Millenium Depelovement Goal's (MDG'S) pada tahun 2015, diharapkan AKI menurun sebesar 102/100.000 KH (Kemenkes RI, 2013).

Terdapat empat persoalan menjadi penyebab tingginya AKI. Hal tersebut mencakup hamil terlalu muda dalam usia $<20$ tahun, terlalu tua dalam usia $>35$ tahun, terlalu rapat dengan jarak kehamilan kurang dari tiga tahun, dan terlalu sering dengan anak lebih dari dua. Selain empat persoalan terlalu tersebut, masih ada tiga terlambat yang menyebabkan AKI masih tinggi. Hal tersebut mencakup terlambat mengenal tanda bahaya, ambil keputusan, dan menuju fasilitas kesehatan. Faktor medis tak menjadi penyebab tunggal dalam empat terlalu dan tiga terlambat. Hal tersebut juga mencakup pembangunan infrastruktur yang memudahkan akses masyarakat menuju fasilitas kesehatan. Sementara Riskesdas 2013 menyebutkan sebesar $16,7 \%$ ibu melahirkan pada usia $<20$ tahun. Semakin muda usia calon ibu maka makin besar kemungkinan untuk menjalani kehamilan berisiko hingga terjadi kematian. Angka pernikahan dini harus ditekan untuk menurunan AKI. Tentunya kesehatan harus didudukung faktor lain misalnya perbaikan ekonomi dan pendidikan, supaya perempuan tidak menikah dini untuk menekan peluang menjalani kehamilan berisiko (Riskesdes, 2013).

Di Sulawesi Selatan Berdasarkan Profil Dinas Kesehatan Provinsi Sulawesi Selatan jumlah AKI tahun 2014 yang dilaporkan menjadi 138 orang atau 93,20 per $100.000 \mathrm{KH}$, terdiri dari kematian ibu hamil 15 orang $(10,68 \%)$, kematian ibu bersalin 54 orang $(39,13 \%)$, kematian ibu nifas 69 orang $(50,00 \%)$. Adapun angka kematian ibu menurut umur yaitu $<20$ tahun sebanyak 14 orang, umur 20-34 tahun sebanyak 87 orang dan $\geq 35$ tahun sebanyak 37 (Profil Kesehatan Provinsi Sulawesi Selatan, 2015).

Menurut data dari Dines Kesehatan jumlah ibu hamil pada tahun 2014 sebanyak 3048 jumlah ibu hamil, tahun 2015 sebanyak 3056, dan pada tahun 2016 sebanyak 3076 ibu hamil, sedangkan kasus hiperemesis gravidarum sebanyak 3 ibu hamil pada tahun 2014, tahun 2015 sebanyak 3 ibu hamil dan pada tahun 2016 sebanyak 4 ibu hamil (Dinas Kesehatan Kota Palopo, 2017). Sedangkan data yang diperoleh dari Puskesmas jumlah kejadian hiperemesis gravidarum pada tahun 2014 sebanyak 16 ibu hamil, pada tahun 2015 sebanyak 8 ibu hamil, dan pada tahun 2016 sebanyak 21 ibu hamil (Puskesmas Wara Selatan Kota Palopo, 2017)

Hal ini sejalan dengan penelitian yang telah dilakukan oleh Santy, dengan judul usia dan paritas terhadap kejadian hiperemesis gravidarum di RSUD Dokter Rubini Mempawah yang mengatakan bahwa ada hubungan usia ibu dengan kejadian hiperemesis gravidarum. Dimana usia ibu $<20$ dan $>35$ tahun 


\section{JURNAL ILMIAH KEBIDANAN

memiliki risiko 2,50 kali lebih besar untuk mengalami hiperemesis gravidarum dibandingkan dengan usia ibu 20-35 tahun $(\mathrm{OR}=2,50)$. Hal ini di tunjukkan dari 95 orang ibu berusia $<20$ dan $>35$ tahun terdapat 58 orang $(62,4 \%)$ yang mengalami hiperemesis gravidarum sedangkan 37 orang $(39,8 \%)$ lainnya tidak mengalami hipermesis gravidarum (Santy, 2015).

Dari hasil penelitian Fitrina, tentang psikologis dari segi kecemasan yaitu dapat dilihat bahwa dari $(35,5 \%)$ responden yang mengalami tingkat kecemasan berat sebanyak $(11,8 \%)$ mengalami hiperemesis gravidarum. Dari $30(58,8 \%)$ responden yang mengalami tingkat kecemasan sedang sebanyak $22(43,1 \%)$ mengalami hiperemsesi gravidarum. Dari $(3,9 \%)$ responden yang mangalami tingkat kecemasan ringan sebanyak $(3,9 \%)$ mengalami hiperemesis gravidarum dan dari $(2,0 \%)$ responden yang mengalami tingkat kecemasan ringan sebanyak (2,0\%) mengalami hiperemesis gravidarum (Fitrina, 2014).

Berdasarkan data tersebut di atas, maka peneliti tertarik melakukan penelitian untuk mengetahui adanya faktor risiko umur ibu dan psikologis dengan kejadian hiperemesis gravidarum

\section{Metode Penelitian}

Desain penelitian yang digunakan dalam penelitian ini adalah case control, dimana penelitian yang mempelajari faktor risiko dengan menggunakan pendekatan retrospektif, artinya penelitian dimulai dengan mengidentifikasi kelompok yang terkena penyakit atau efek tertentu (kasus) dan kelompok tanpa efek (kontrol), kemudian mengidentifikasi faktor risiko terjadinya pada waktu yang lalu, sehingga dapat menerangkan mengapa kasus terkena efek, sedangkan kontrol tidak terkena efek.

Populasi dalam penelitian ini adalah semua ibu hamil di wilayah Puskesmas Wara Selatan Kota Palopo Tahun 2017 yang tercatat di rekam medik yaitu 25 ibu hamil yang mengalami hiperemesis gravidarum dan $50 \mathrm{ibu}$ hamil yang tidak mengalami hiperemesis gravidarum periode bulan April-Juli 2017. Penelitian ini dilaksanakan pada periode bulan April-Juli 2017 di wilayah kerja Puskesmas Wara Selatan kota Palopo.

Teknik pengumpulan data ada dua yaitu data primer dan data sekunder. Data primer diperoleh dengan cara membagikan kuesioner yang telah disediakan kepada responden. Responden dibagi menjadi 2 yaitu kasus dan kontrol. Setelah data dikumpulkan kemudian dianalisis menggunakan SPSS.

Variabel bebas dan terikat pada penelitian ini: umur ibu dan psikologis sebagai bariabel bebas. Kejadian hiperemesis gravidarum sebagai variabel terikat. Instrumen dalam penelitian ini kuesioner dalam bentuk lebar checklist. Analisa data yang digunakan adalah Odss Ratio.

\section{Hasil dan Pembahasan}

Tabel 1 Distribusi Frekuensi Berdasarkan Umur Ibu pada kelompok Kasus

\begin{tabular}{ccc}
\hline Umur Ibu & Frekuensi (f) & Persentase (\%) \\
\hline Risiko Tinggi & 20 & 80,0 \\
Risiko Rendah & 5 & 20,0 \\
\hline Total & $\mathbf{2 5}$ & $\mathbf{1 0 0}$ \\
\hline
\end{tabular}

Tabel 2 Distribusi Frekuensi Berdasarkan Umur Ibu pada kelompok kontrol

\begin{tabular}{lcc}
\hline \multicolumn{1}{c}{ Umur Ibu } & Frekuensi (f) & Persentase (\%) \\
\hline Risiko Tinggi & 21 & 42,0 \\
Risiko Rendah & 29 & 58,0 \\
\hline Total & $\mathbf{5 0}$ & $\mathbf{1 0 0}$ \\
\hline
\end{tabular}

Tabel 3 Distribusi Frekuensi Berdasarkan Psikologis pada kelompok Kasus

\begin{tabular}{clcc}
\hline & Psikologis & Frekuensi (f) & Persentase (\%) \\
\hline & Terganggu & 21 & 84,0 \\
& Tidak Terganggu & 4 & 16,0 \\
\hline Total & & $\mathbf{2 5}$ & $\mathbf{1 0 0}$ \\
\hline
\end{tabular}


Tabel 4 Distribusi Frekuensi Berdasarkan Psikologis pada kelompok Kontrol

\begin{tabular}{|c|c|c|}
\hline Psikologis & Frekuensi (f) & Persentase (\%) \\
\hline Terganggu & 32 & 64,0 \\
\hline Tidak Terganggu & 18 & 36,0 \\
\hline Total & 50 & 100 \\
\hline
\end{tabular}

Tabel 5 Distribusi Faktor Risiko Kejadian Hipremesis Gravidarum berdasarkan Umur Ibu

\begin{tabular}{|c|c|c|c|c|c|c|c|c|c|}
\hline \multirow{3}{*}{ Umur Ibu } & \multicolumn{6}{|c|}{ Hiperemesis Gravidarum } & \multirow{3}{*}{ OR } & \multicolumn{2}{|c|}{$95 \%$ CI } \\
\hline & \multicolumn{2}{|c|}{ Kasus } & \multicolumn{2}{|c|}{ Kontrol } & \multicolumn{2}{|c|}{ Total } & & \multirow{2}{*}{$\begin{array}{c}\text { Lower } \\
\text { Limit }\end{array}$} & \multirow{2}{*}{ Upper Limit } \\
\hline & $\mathbf{N}$ & $\%$ & $\mathbf{N}$ & $\%$ & $\mathbf{N}$ & $\%$ & & & \\
\hline Risiko Tinggi & 20 & 80,0 & 21 & 42,0 & 41 & 54,7 & \multirow{2}{*}{5,52} & \multirow{2}{*}{1,78} & \multirow{2}{*}{17,09} \\
\hline Risiko Rendah & 5 & 20,0 & 29 & 58,0 & 34 & 45,3 & & & \\
\hline Total & 25 & 100 & 50 & 100 & 75 & 100 & & & \\
\hline
\end{tabular}

Sumber: Hasil Uji Odss Ratio

Tabel 6 Distribusi Faktor risiko Kejadian Hipremesis Gravidarum berdasarkan Psikologis

\begin{tabular}{|c|c|c|c|c|c|c|c|c|c|}
\hline \multirow{3}{*}{ Psikologis } & \multicolumn{6}{|c|}{ Hiperemesis Gravidarum } & \multirow{3}{*}{ OR } & \multicolumn{2}{|c|}{$95 \% \mathrm{CI}$} \\
\hline & \multicolumn{2}{|c|}{ Kasus } & \multicolumn{2}{|c|}{ Kontrol } & \multicolumn{2}{|c|}{ Total } & & \multirow{2}{*}{$\begin{array}{c}\text { Lower } \\
\text { Limit }\end{array}$} & \multirow{2}{*}{ Upper Limi } \\
\hline & $\mathbf{n}$ & $\%$ & $\mathbf{N}$ & $\%$ & $\mathbf{N}$ & $\%$ & & & \\
\hline Terganggu & 21 & 84,0 & 32 & 46,0 & 53 & 70,7 & \multirow{2}{*}{2,95} & \multirow{2}{*}{, 87} & \multirow{2}{*}{9,95} \\
\hline Tidak terganggu & 4 & 16,0 & 18 & 36,0 & 22 & 29,3 & & & \\
\hline Total & 25 & 100 & 50 & 100 & 75 & 100 & & & \\
\hline
\end{tabular}

Sumber: Hasil Uji Odss Ratio

Berdasarkan data pada tabel 5 menunjukkan dari 75 responden sebanyak $41(54,7 \%)$ orang yang memiliki risiko tinggi dimana $20(80,0 \%)$ orang termasuk dalam kelompok kasus dan $21(42,0 \%)$ orang lainnya termasuk dalam kelompok kontrol. Sedangkan 34 (45,3\%) orang memiliki risiko rendah dimana 5 $(20,0 \%)$ orang termasuk dalam kelompok kasus dan $29(58,0 \%)$ orang lainnya termasuk dalam kelompok kontrol.

Hasil uji OR dengan $95 \%$ CI diperoleh nilai OR $=5,52$. Hal ini menunjukkan bahwa ibu hamil dengan umur ibu risiko tinggi, berisiko 5,52 kali lebih besar mengalami hiperemesis gravidarum dibanding dengan ibu hamil dengan umur risiko rendah, karena nilai OR $>1$, maka umur ibu merupakan faktor risiko kejadian hiperemesis gravidarum.

Oleh karena nilai lower limit 1,78 dan upper limit 17,09 tidak mencakup nilai 1 sehingga nilai OR yang diperoleh bermakna secara statistik.

Hal ini sejalan dengan penelitian yang telah dilakukan oleh Santy dengan judul usia dan paritas terhadap kejadian hiperemesis gravidarum di RSUD Dokter Rubini Mempawah yang mengatakan bahwa ada hubungan usia ibu dengan kejadian hiperemesis gravidarum. Dimana usia ibu $<20$ dan $>35$ tahun memiliki risiko 2,50 kali lebih besar untuk mengalami hiperemesis gravidarum dibandingkan dengan usia ibu 20-35 tahun $(\mathrm{OR}=2,50)$. Hal ini di tunjukkan dari 95 orang ibu berusia $<20$ dan $>35$ tahun terdapat $62,4 \%$ (58 orang) yang mengalami hiperemesis gravidarum sedangkan 39,8\% (37 orang) lainnya tidak mengalami hipermesis gravidarum (Santy, 2015).

Hal ini juga sejalan dengan penelitian yang dilakukan oleh Masruroh dan Ikke, tentang hubungan antara umur ibu dan gravida dengan kajadian hiperemesis gravidarum di RSUD Ambarawa Kabupaten Semarang Tahun 2015 yang mengatakan bahwa tingkat risiko antara faktor umur dengan kejadian hiperemesis gravidarum ditunjukkan dengan nilai OR sebesar 2,52, sehingga dapat dinyatakan bahwa umur ibu yang berisiko, cenderung mengalami hiperemesis gravidarum 2,52 kali lebih besar dibandingkan umur ibu yang tidak berisiko. Nilai $\mathrm{CI}=5,531-1,148$ artinya umur ibu berisiko memiliki risiko terendah 1,14. kali dan risiko tertinggi 5,53 kali untuk mengalami hiperemesis gravidarum (Masruroh. \& Retnosari, 2016). 


\section{JURNAL ILMIAH KEBIDANAN \\ E-ISSN 2774 - 4671

Namun, penelitian lain juga beranggapan bahwa hiperemesis gravidarum tidak hanya terjadi pada ibu dengan usia resiko tinggi, namun juga banyak terjadi pada usia resiko rendah, tentunya ini disebabkan oleh faktor lain seperti kurangnya dukungan keluarga, rendahnya pendidikan ibu dan sebagainya (Layuza, 2014)

Hal ini sesuai dengan teori yang dikemukakan oleh Santy bahwa kehamilan adalah waktu penolakan fisik dan psikologik yang dahsyat, stres dapat memperberat mual dan muntah yang diinduksikan secara hormonal yang dapat menyebabkan gangguan kehamilan dan pertumbuhan janin. Usia reproduksi yang optimal bagi seorang ibu adalah usia 20-35 tahun, pada usia $<20$ tahun rahim dan panggul ibu belum tumbuh mencapai ukuran dewasa dan pada usia $>35$ tahun organ kandungan sudah tua sehingga jalan lahir telah kaku dan mudah terjadi komplikasi mual dan muntah terjadi pada umur $<20$ tahun disebabkan karena belum cukupnya kematangan fisik, mental dan fungsi sosial dari calon ibu sehingga dapat menimbulkan keraguan jasmani, cinta kasih, dan perawatan serta asuhan bagi anak yang akan dilahirkannya. Sedangkan mual dan muntah yang terjadi $>35$ tahun disebabkan oleh faktor psikologis, dimana ibu belum siap hamil lagi atau bahkan tidak menginginkan kehamilannya lagi sehingga akan merasa sedemikian tertekan dan menimbulkan stres pada ibu (Santy, 2015).

Hal ini sejalan dengan teori yang dikemukakan Andani, bahwa umur ibu mempunyai pengaruh yang erat dengan perkembangan alat reproduksi. Hal ini berkaitan dengan keadaan fisiknya dari organ tubuh ibu didalam menerima kehadiran dan mendukung perkembangan janin. Seorang wanita memasuki usia perkawinan atau mengakhiri fase tertentu dalam kehidupannya yaitu umur reproduksi. Umur reproduksi yang ideal bagi wanita untuk hamil dan melahirkan adalah 20-35 tahun., keadaan ini disebabkan karena pada umur kurang dari 20 tahun rahim dan panggul ibu belum berkembang dengan baik dan belum cukup dewasa untuk menjadi ibu sedangkan pada umur $>35$ tahun elastisitas otot-otot panggul dan sekitarnya serta alat-alat reproduksi pada umumnya telah mengalami kemunduran sehingga dapat mempersulit persalinan dan selanjutnya dapat menyebabkan kematian pada ibu (Andani, 2014).

Berdasarkan tabel 6 menunjukkan dari 75 responden sebanyak $53(70,7 \%)$ orang yang mengalami gangguan psikologis dimana $21(84,0 \%)$ orang termasuk dalam kelompok kasus dan $32(64,0 \%)$ orang lainnya termasuk dalam kelompok kontrol. Sedangkan 22 (29,3\%) orang yang tidak mengalami gangguan psikologis dimana $4(16,0 \%)$ orang termasuk dalam kelompok kasus dan $18(36,0 \%)$ orang lainnya termasuk dalam kelompok kontrol.

Hasil uji OR dengan 95\% CI diperoleh nilai OR $=2,95$. Hal ini menunjukkan bahwa ibu hamil dengan gangguan psikologis, beresiko 2,95 kali lebih besar mengalami hiperemesis gravidarum dibanding dengan ibu hamil yang tidak mengalami gangguan psikologis karena nilai OR $>1$, maka psikologis merupakan faktor risiko kejadian hiperemesis gravidarum.

Oleh karena nilai lower limit ,87 dan upper limit 9,95 tidak mencakup nilai 1 sehingga nilai OR yang diperoleh bermakna secara statistik.

Hal ini sejalan dengan penelitian yang telah dilakukan oleh Fitrina, tentang hubungan tingkat kecemasan ibu hamil trimester I dengan kejadian hiperemesis gravidarum di wilayah kerja Puskesmas Pelembayan Jorong Koto Tinggi Tahun 2014 mengatakan bahwa dari $(35,5 \%)$ responden yang mengalami tingkat kecemasan berat, sebanyak $(11,8 \%)$ mengalami hiperemesis gravidarum. Dari $30(58,8 \%)$ responden yang mengalami tingkat kecemasan sedang sebanyak $22(43,1 \%)$ mengalami hiperemesis gravidarum. Dari (3.,9\%) responden yang mengalami tingkat kecemasan ringan sebanyak $(3,9 \%)$ mengalami hiperemesis gravidarum. Dan dari $(2,0 \%)$ responden yang mengalami tingkat kecemasan ringan sebanyak (2,0\%) mengalami hiperemesis gravidarum (Fitrina, 2014).

Hal ini sejalan dengan penelitian yang dilakukan oleh Sulistyowati, Edy \& Indri, tentang hubungan antara tingkat stres dengan kejadian hiperemesis gravidarum pada ibu hamil trimester I di BPS Ny. Sayidah Kendal Tahun 2012 yang mengatakan bahwa dari 79 responden terdapat 63 responden yang mengalami tingkat kecemasan ringan dimana 3 responden $(4,48 \%)$ yang mengalami hiperemesis gravidarum dan 60 responden $(9,2 \%)$ yang tidak mengalami hiperemesis gravidarum sedangkan 16 responden yang mengalami tingkat kecemasan sedang dimana 14 responden $(87,5 \%)$ yang mengalami hiperemesis gravidarum dan 2 responden (2\%) yang tidak mengalami hiperemesis gravidarum (Sulistyowati et,al., 2012)

Hal ini sejalan dengan teori yang dikemukakan oleh Rukiyah, bahwa ibu hamil sangat memerlukan dukungan dan perhatian dari keluarga dan tenaga kesehatan. Adanya dukungan ini menyebabkan ibu merasa aman dan nyaman dalam melewati kehamilannya psikologis ibu hamil sangat unik dan sensitif, 


\section{JURNAL ILMIAH KEBIDANAN

oleh karena dukungan yang diberikan harus serius dan maksimal. Apabila ibu melewati kehamilannya dengan perasaan tidak aman dan nyaman yang disebakan oleh faktor lingkungan akan menyebabkan gangguan yang berarti bagi ibu dan janin (Rukiyah et. al., 2014)

\section{Kesimpulan}

Faktor risiko kejadian hiperemesis gravidarum ibu hamil dengan umur risiko tinggi berisiko 5,52 kali lebih besar dibandingkan ibu hamil dengan umur resiko rendah.

Faktor risiko kejadian hiperemesis gravidarum ibu hamil yang mengalami gangguan psikologis berisiko 2,95 kali lebih besar dibandingkan dengan ibu hamil yang tidak mengalami gangguan psikologis.

Diharapkan dapat menambah referensi untuk memberikan informasi dan saran kepada mahasiswa program studi kebidanan khususnya mengenai faktor risiko risiko umur ibu dan psikologis dengan kejadian hiperemesis gravidarum agar memudahkan mahasiswa yang ingin melakukan penelitian selanjutnya dapat menjadi lebih baik dibandingkan pembuatan Karya Tulis Ilmiah lainnya.

Diharapkan dapat menjadi tambahan informasi dalam meningkatkan pelayanan kebidanan yang sudah baik agar menjadi lebih baik lagi khususnya informasi tentang faktor risiko umur ibu dan psikologis dengan kejadian hiperemesis gravidarum.

\section{Referensi}

Andani, D.R.A. Faktor Risiko Hiperemesis Gravidarum Pada Ibu Hamil Di Puskesmas Kapongan Kecamatan Kapoongan Situbondo. 2014.

Dinas Kesehatan Kota Palopo. Jumlah Ibu Hamil Tahun 2014-2016. 2017.

Fauziyah, Y. Obstetri Patologi untuk Mahasiswa Kebidanan dan Keperawatan. Yogyakarta, IN: Nuha Medika. 2012.

Fitrina, Y. Hubungan Tingkat Kecemasan Ibu Hamil Trimester I Dengan Kejadian Hiperemesis Gravidarum Di Wilayah Kerja Puskesmas Palembayan Jorong Koto Tnggi Tahun 2014. Hal: 4. 2014.

Kemenkes RI. Penatalaksanaan Asuhan Kegawatdaruratan Ibu Hamil. Jakarta, Dikjen Yankes. 2013. Layuza. Hubungan Paritas, Umur Terhadap Kejadian Hiperemesis Gravidarum Pada Ibu Hamil Di Puskesmas Pakan Rabaa Dan Halaban Kecamatan Lareh Sagohalaban Tahun 2014. 2014

Manuaba, I.A.C, Manuaba, I.B.G.F. \& Manuaba, I.B.G. Ilmu Kebidanan, Penyakit Kandungan, dan KB. EDISI 2. Jakarta, IN: EGC. 2014.

Masruroh. \& Retnosari. I. Hubungan Antara Umur Ibu Dan Gravida Dengan Kejadian Hiperemesis Gravidarum Di RSUD Ambarawa Kabupaten Semarang. 2016.

Prawirohardjo, S. Ilmu Kandungan. Jakarta, IN: P.T. Bina Pustaka Sarwono Prawirohardjo. 2014.

Profil Kesehatan Provinsi Sulawesi Selatan. Angka Kematian Ibu Maternal Di Sulawesi Selatan Tahun 2009-2014. 2015.

Puskesmas Wara Selatan Kota Palopo. Jumlah Ibu Hamil Tahun 2014-2016. 2017.

Riskesdes. 2013.

Rukiyah, A.Y. dkk. Asuhan Kebidanan 4 Patologi Kebidanan. Jakarta, IN: Tim Inti Medika. 2014.

Santy, E. Usia Dan Paritas Terhadap Kejadian Hiperemesis Gravidarum Di RSUD Dokter Rubini Mempawah. Volume 1 Nomor 2. Juli 2015. Hal 60-65. 2015.

Sulistyowati, Soesanto, E, \& Purwanti, I.A. Hubungan Antara Tingkat Stress Dengan Kejadian Hiperemesis Gravidarum Pada Ibu Hamil Trimester I Di BPS Ny. Sayidah Kendal. 2012

Warsuli, Saparwati, M, \& Purbowati. Hubungan Primigravida Terhadap Kejadian Hiperemesis Gravidarum Di Puskesmas Pringapus Kecamatan Pringapus Kabupaten Semarang Tahun 2016. 2016.

WHO. Angka Kematian Ibu Tahun 2014. Dikutip dari http://www.depkes.go.id>infodatin-ibu._2015. 